\title{
Hydrogen Production by Supercritical Water Gasification of Biomass with Homogeneous and Heterogeneous Catalyst
}

\author{
Hui Jin, Youjun Lu, Liejin Guo, Ximin Zhang, and Aixia Pei \\ State Key Laboratory of Multiphase Flow in Power Engineering, Xian Jiaotong University, Xian 710049, China \\ Correspondence should be addressed to Liejin Guo; lj-guo@mail.xjtu.edu.cn
}

Received 13 March 2014; Accepted 11 May 2014; Published 16 June 2014

Academic Editor: Shaohua Shen

Copyright ( 2014 Hui Jin et al. This is an open access article distributed under the Creative Commons Attribution License, which permits unrestricted use, distribution, and reproduction in any medium, provided the original work is properly cited.

\begin{abstract}
Biomass gasification in supercritical water is a clean and efficient way to convert biomass to hydrogen-rich gaseous products. Appropriate catalyst can lower the reaction temperature to guarantee the technological and economic feasibility. This paper selects $\mathrm{Ca}(\mathrm{OH})_{2}, \mathrm{Na}_{2} \mathrm{CO}_{3}, \mathrm{~K}_{2} \mathrm{CO}_{3}, \mathrm{NaOH}, \mathrm{KOH}, \mathrm{LiOH}$, and $\mathrm{ZnCl}_{2}$ as typical homogeneous catalysts and three kinds of Raney-Ni, dolomite, and olivine as typical heterogeneous catalysts. The catalyst effects are investigated in the process of biomass gasification in supercritical water with the temperature of $400^{\circ} \mathrm{C}$, pressure of $22 \sim 24 \mathrm{MPa}$, and residence time of $20 \mathrm{~min}$. The experimental results show that Raney-Ni has the best hydrogen selectivity and hydrogen yield. The mixture of $\mathrm{NaOH}$ with Raney-Ni was investigated in order to research the synergistic effect of different catalysts. The experimental results show that Raney- $\mathrm{Ni}$ and $\mathrm{NaOH}$ have a synergistic effect in the biomass gasification in supercritical water.
\end{abstract}

\section{Introduction}

Biomass has the potential to provide the increasing energy demand of the world due to the large world-wide resource potential and the optimistic long-term contribution [1]. The clean and efficient utilization of biomass is the object of growing attention due to the environmental and economic reasons [2].

Supercritical water gasification has recently received significant attention as a potential alternative to energy conversion method [3-6]. It has an obvious advantage in converting biomass directly without high energy-consuming drying process to obtain high energy efficiency [7]. Due to the unique physical properties of water above its critical conditions (i.e., $374.15^{\circ} \mathrm{C}$ and $22.1 \mathrm{MPa}$ ), most of hydrogen bonds break [8-10] and offer a controlling mechanism depending on operating parameter and have an excellent transport properties based on their high diffusion ability, low viscosity, and new reaction alternatives for hydrolysis or oxidation [11, 12]. Organic compounds have complete miscibility in supercritical water, and chemical reactions have high efficiency due to the absence of interfacial transport limitations $[4,12]$. Air-polluting species containing $\mathrm{N}$ and $S$ are not produced because supercritical water gasification conducts in relatively low temperature [13]. $\mathrm{CO}_{2}$ can easily be enriched and separated owing to the difference in solubility between $\mathrm{CO}_{2}$ and other gaseous products [14]. The energy of fluid after reaction can be easily recovered by steam turbine [6].

Catalyst can decrease the reaction temperature and accelerate the reaction to guarantee the technological and economic feasibility of supercritical water gasification and conduct the reaction toward the desired products [15], so catalytic gasification of biomass in supercritical water has received much attention, and the catalyst investigated can roughly be divided into homogenous and heterogonous catalysts $[16,17]$.

As for homogenous catalyst, it is easy to be mixed with feedstock and is easy to operate for the gasification system. Researchers mainly focus on the alkaline metal catalyst such as $\mathrm{KOH}[18,19], \mathrm{NaOH}[20-22], \mathrm{K}_{2} \mathrm{CO}_{3}$ [23-27], $\mathrm{Ca}(\mathrm{OH})_{2}$ $[28,29]$, and $\mathrm{KHCO}_{3}$ [30]. It is generally accepted that the water-gas shift reaction is accelerated by alkaline metal. Formic acid is assumed to be the intermediate product in the reaction process, and $\mathrm{H}_{2}$ and $\mathrm{CO}_{2}$ are produced through the pathway of formic acid decomposition. Alkali can also absorb $\mathrm{CO}_{2}$ so that water-gas shift reaction can conduct toward the 
hydrogen production direction. However, the solubility of inorganic salt in supercritical water is significantly lower than the ambient condition and the eutectic melting of inorganic salt is observed, which may cause trouble in the continuous operation of the gasification system [28].

As for the heterogeneous catalyst, researchers have done extensive job in the screening of the active metal and supporting material to find a catalyst with high activity, hydrothermal stability, and resistance to carbon deposition [31]. Ni-based catalyst is frequently studied due to its relatively low price and high activity. However, hydrothermal instability and carbon deposition are still two big problems for the Ni-based catalyst development [32-34]. Activated carbon gained attention as a potential catalyst for hydrothermal gasification because activated carbon has high activity and does not introduce any pollution to the reaction system. But activated carbon is apt to have deactivation problems $[8,35,36]$. Expensive metal also gained attention due to the extremely high catalytic effects; however, the high price restricts its large-scale industrial application [37-39].

It can be observed that neither homogeneous catalyst nor heterogeneous catalyst is provided with all the advantages. Several typical homogeneous and heterogeneous catalysts are investigated in this paper to study the biomass gasification characteristics of biomass in order that optimal catalyst selection method can be obtained. Minowa and Ogi [40] studied the catalytic effect of mixture of $\mathrm{Ni}$ and $\mathrm{Na}_{2} \mathrm{CO}_{3}$ in a autoclave at the temperature of $350^{\circ} \mathrm{C}$ and pressure range of $18 \sim 20 \mathrm{MPa}$ in the process of thermochemical conversion of cellulose and the synergistic effect was found. This paper will investigate the synergistic effect of homogeneous catalyst and heterogeneous catalyst in supercritical water gasification condition.

\section{Experimental Section}

2.1. Material. Peanut shell is selected as typical real biomass which is produced in the city of Huanggang, Hubei Province. It is ground until the size of biomass particle is smaller than $180 \mu \mathrm{m}$. The ultimate analysis and proximate analysis of real biomass can be seen in Table 1. A small quantity of Carboxy methylated cellulose (CMC) is added into the slurry to make a uniform solution. Different types of Raney-Ni are prepared by Dalian general chemical Co., LTD, and the metal element analysis of Raney nickel catalyst (RTH-3110, RTH4110, RTH-5110) can be seen in Table 2. $\mathrm{LiOH}, \mathrm{KOH}, \mathrm{NaOH}$, $\mathrm{Ca}(\mathrm{OH})_{2}, \mathrm{Na}_{2} \mathrm{CO}_{3}$, and $\mathrm{K}_{2} \mathrm{CO}_{3}$ are analytic reagent. Olivine and dolomite are provided by the Yingkou Hepingsanhua Mineral Co., Ltd. They are ground until the particle size is smaller, $106 \mu \mathrm{m}$ and $55 \mu \mathrm{m}$, respectively.

2.2. Experimental Apparatus and Procedure. Gasification of biomass is carried out in a $140 \mathrm{~mL}, 316 \mathrm{~L}$ stainless steel, highpressure autoclave. Detailed description of the experimental apparatus was published before [41]. Firstly, $11 \mathrm{~g}$ solution of $9.09 \mathrm{wt} \%$ glucose and $0.2 \mathrm{~g}$ catalyst is added to the reactor for these experiments. The reactor was heated from ambient temperature to the reaction temperature with a heating rate of about $17 \mathrm{~K} / \mathrm{min}$. After gasification reaction, the reactor is cooled down below $473 \mathrm{~K}$ in $1 \mathrm{~min}$ and then below $373 \mathrm{~K}$ in $2.5 \mathrm{~min}$.

2.3. Analytical Method. The sampled gases were analyzed by a Hewlett-Packard model 6890 gas chromatograph (GC) with a thermal conductivity detector. A Carbon-2000 capillary column was used $(\Phi 0.53 \mathrm{~mm} \times 25 \mathrm{~m})$, operating at $333 \mathrm{~K}$ for $7 \mathrm{~min} . \mathrm{N}_{2}$ was adopted as the carrier gas with the flow rate of $10 \mathrm{~mL} / \mathrm{min}$. A standard gas mixture with 6 kinds of species $\left(\mathrm{H}_{2}, \mathrm{CO}, \mathrm{CO}_{2}, \mathrm{CH}_{4}, \mathrm{C}_{2} \mathrm{H}_{4}\right.$, and $\left.\mathrm{C}_{2} \mathrm{H}_{6}\right)$ is employed for calibration and bought from and compounded by Nanjing Special Gas Co., Ltd. in China.

\section{Homogeneous and Heterogeneous Catalyst}

3.1. Homogeneous Catalysts. The experimental balance and enhancement of the addition of homogeneous catalyst upon the biomass gasification are seen in Tables 3 and 4, respectively. The yield of hydrogen is $2.86 \mathrm{mmol} / \mathrm{g}$ with no catalyst added. The presence of the catalyst increased the yield of hydrogen. $\mathrm{KOH}$ has the best catalytic effect and the amplification of hydrogen yield is $144.76 \% . \mathrm{Ca}(\mathrm{OH})_{2}$ takes the second place. The amplification is $132.87 \%$. $\mathrm{NaCO}_{3}$ has the worst catalytic effect and the amplification is only $9.79 \%$. Meanwhile, the fraction of hydrogen increases at the same time. When $\mathrm{Ca}(\mathrm{OH})_{2}$ is added, the fraction of hydrogen is $48.54 \%$. The order of catalytic effect on hydrogen yield of biomass gasification is as follows: $\mathrm{KOH}>\mathrm{Ca}(\mathrm{OH})_{2}>$ $\mathrm{K}_{2} \mathrm{CO}_{3}>\mathrm{LiOH}>\mathrm{NaOH}>\mathrm{Na}_{2} \mathrm{CO}_{3}$. The order of catalytic effect on hydrogen fraction of biomass gasification is as follows: $\mathrm{LiOH}>\mathrm{Ca}(\mathrm{OH})_{2}>\mathrm{KOH}>\mathrm{K}_{2} \mathrm{CO}_{3}>\mathrm{NaOH}>$ $\mathrm{Na}_{2} \mathrm{CO}_{3}$.

As for the comparison of hydrogen yield between the alkali carbonate and alkali hydroxide, the influence of alkali metal cation $\left(\mathrm{Na}^{+}, \mathrm{K}^{+}\right)$is far more than that of anion $\left(\mathrm{CO}_{3}{ }^{2-}\right.$, $\mathrm{OH}^{-}$). Comparison between $\mathrm{LiOH}, \mathrm{NaOH}$, and $\mathrm{KOH}$ shows that the stronger the alkalinity is, the weaker the catalytic effect is for hydrogen production.

It can be seen that when basic catalysts are added, the yield of CO decreases sharply, that is probably due to catalytic effect of basic catalyst upon the water-gas shift reaction. The amount of $\mathrm{CO}_{2}$ decreases compared with the reaction situation without catalyst because $\mathrm{CO}_{2}$ is absorbed by the basic catalysts (especially $\mathrm{LiOH}, \mathrm{NaOH}, \mathrm{KOH}$, and $\mathrm{Ca}(\mathrm{OH})_{2}$ ) as carbonates. For example, $\mathrm{Ca}(\mathrm{OH})_{2}$ is used in HyPr-RING by Lin et al. [28] to absorb $\mathrm{CO}_{2}$ and to integrate water-gas shift reaction and $\mathrm{CO}_{2}$ absorption reaction in one reactor. The reactions are as follows:

$$
\begin{gathered}
\mathrm{Ca}(\mathrm{OH})_{2}+2 \mathrm{CO} \longrightarrow(\mathrm{HCOO})_{2} \mathrm{Ca} \\
(\mathrm{HCOO})_{2} \mathrm{Ca}+2 \mathrm{H}_{2} \mathrm{O} \longrightarrow \mathrm{Ca}\left(\mathrm{HCO}_{3}\right)_{2}+2 \mathrm{H}_{2} \\
\mathrm{Ca}\left(\mathrm{HCO}_{3}\right)_{2} \longrightarrow \mathrm{CO}_{2}+\mathrm{CaCO}_{3}+\mathrm{H}_{2} \mathrm{O}
\end{gathered}
$$

It can be seen that although the presence of basic catalyst increases the yield of hydrogen and methane, carbon gasification efficiency increases. Basic catalyst has catalytic 
TABLE 1: Elemental and proximate analysis of peanut shell.

\begin{tabular}{lccccccccc}
\hline \multirow{2}{*}{ Biomass } & \multicolumn{4}{c}{ Elemental analysis (wt\%) } & \multicolumn{3}{c}{ Proximate analysis (wt\%) } \\
& $\mathrm{C}$ & $\mathrm{H}$ & $\mathrm{N}$ & $\mathrm{S}$ & $\mathrm{O}$ & $\mathrm{M}$ & $\mathrm{A}$ & $\mathrm{V}$ & $\mathrm{FC}$ \\
\hline Peanut shell & 43.80 & 4.92 & 1.52 & 0.17 & 34.10 & 7.99 & 7.50 & 65.85 \\
\hline
\end{tabular}

TABLE 2: Metal element analysis of Raney nickel catalyst.

\begin{tabular}{lcccc}
\hline Type & Active metal & Promoter & Al & Particle size $/ \mu \mathrm{m}$ \\
\hline RTH-3110 & $\sim 90 \mathrm{wt} \% \mathrm{Ni}$ & $1 \mathrm{wt} \% \mathrm{Mo}$ & $4-10 \mathrm{wt} \%$ & 50 \\
RTH-4110 & $\sim 85 \mathrm{wt} \% \mathrm{Ni}$ & $2 \mathrm{wt} \% \mathrm{Fe}, 2.5 \mathrm{wt} \% \mathrm{Cr}$ & $8-12 \mathrm{wt} \%$ & 50 \\
RTH-5110 & $\sim 75 \mathrm{wt} \% \mathrm{Ni}$ & $15 \mathrm{wt} \% \mathrm{Fe}$ & $4-10 \mathrm{wt} \%$ & 32 \\
\hline
\end{tabular}

effect on water-gas shift reaction, and its catalytic effects are reported in earlier publication [18]

On the other hand, basic effect has an important effect in the process of biomass hydrolysis. Sinağ et al. studied the function of $\mathrm{K}_{2} \mathrm{CO}_{3}$ in the process of glucose gasification in supercritical water. It is found that $\mathrm{K}_{2} \mathrm{CO}_{3}$ is in favor for the decomposition of glucose to formic acid and restrained furfurals formation. And formic acid is regarded as an intermediate of gas formation. Furfurals can be converted to be phenols and produce tar and coke. Therefore, the presence of $\mathrm{K}_{2} \mathrm{CO}_{3}$ increases the yield of gas and restrained tar and coke production $[26,42]$.

Encinar et al. [43] reported that metal chloride such as $\mathrm{LiCl}, \mathrm{NaCl}, \mathrm{KCl}$, and $\mathrm{ZnCl}_{2}$ has a catalytic effect in the process of bagasse gasification. $\mathrm{ZnCl}_{2}$ has an obvious promotion in the process of hydrogen production especially. When $\mathrm{ZnCl}_{2}$ is used as catalyst, a great amount of char particles are produced, and viscous black tarry substance is produced as well, which is a typical phenomenon of incomplete gasification. Although the carbon gasification efficiency remains constant, the hydrogen selectivity increases sharply and the yield of hydrogen increases by $82.5 \%$ because $\mathrm{ZnCl}_{2}$ has the function of swelling and dissolution and can permeate into the inner place of feedstock so as to form a small opening to increase the contact area of the catalyst and biomass matrix.

3.2. Heterogeneous Catalysts. The experimental balance and enhancement of the addition of heterogeneous catalyst upon the biomass gasification are seen in Tables 5 and 6 , respectively. Three kinds of Raney-Ni (RTH-3110, RTH-4110, and RTH-5110) are selected as typical Raney-Ni. They obtained carbon gasification efficiency of $66.73 \%, 59.66 \%$, and $53.07 \%$, respectively, among which RTH-3110 holds the highest carbon gasification efficiency. The three kinds of Raney-Ni have the hydrogen yield of $9.57,8.34$, and $10.78 \mathrm{mmol} / \mathrm{g}$ gas yield compared with $2.86 \mathrm{mmol} / \mathrm{g}$ without catalyst.

Raney-Ni is mainly $[44,45]$ a fine-ground solid composed mostly of nickel derived from a nickel-aluminum alloy, and there are trace elements spread in nickel-aluminum. The lattice defects in the metallic surface and the trace elements increase catalytic effects. The metal analyses for the three catalysts are shown in Table 2. It can be seen from Table 5 that different trace elements have distinct catalytic effects. RTH-5110 doping with Fe has the highest hydrogen yield, because $\mathrm{Fe}$ is in the eighth main group in the periodic table of the elements, and the $\mathrm{Ru}, \mathrm{Rh}, \mathrm{Pd}$, and $\mathrm{Ni}$ have been proved to be an effective catalyst for biomass gasification in supercritical water. Elements in the eighth main group have strong chemical absorption for reactant, so that elements in this main group show catalytic ability in relatively low temperature. Compared with RTH-4110, RTH-3110 has better catalytic effect in hydrogen production. It can be seen that addition of Mo favors hydrogen production from biomass more obviously than $\mathrm{Cr}$. It can provide useful information for home-made catalysts development.

As for the gasification of coal in a pipe flow continuous experimental device operated by Li et al. [23], gasification efficiency, carbon gasification efficiency, and hydrogen gasification efficiency with $\mathrm{K}_{2} \mathrm{CO}_{3}$ are higher than those with Raney-Ni, because Raney-Ni powder is not well distributed as particles, and $\mathrm{K}_{2} \mathrm{CO}_{3}$ dissolves in water to form a uniform solution.

It can be seen from Table 6 that olivine and dolomite have a catalytic effect on biomass gasification. They increase hydrogen yield by $46.2 \%$ and $37.8 \%$, respectively, compared with the reaction condition without catalyst. Although their catalytic effects are not as high as $\mathrm{KOH}$ and $\mathrm{Ca}(\mathrm{OH})_{2}$, they are still higher than that of $\mathrm{Na}_{2} \mathrm{CO}_{3}$ and $\mathrm{NaOH}$. The fraction of hydrogen increases with the addition of dolomite and olivine. Complex of $\mathrm{CaO}-\mathrm{MgO}$ is generated by calcinations and it is a mixed oxide acid-base type catalyst with polar active sites. These active sites can absorb hydrocarbon and break the $\mathrm{C}-\mathrm{C}$ and $\mathrm{C}-\mathrm{H}$ bond to obtain gas and liquid product in small molecular in the hydrogen production reaction of biomass gasification in supercritical water. Dolomite also has a catalytic effect on the decomposition of tar and coke with large molecular. Because tar contains a great amount of condensed ring with electronegative $\pi$-electron system so they can be absorbed in the $\pi$-shaped electron cloud and lose stability and make $\mathrm{C}-\mathrm{C}$ bond and $\mathrm{C}-\mathrm{H}$ bond broken easily, so as to lower the activation energy of pyrolysis. Olivine also has good catalytic effect in biomass gasification and is commonly used in traditional biomass gasification process. What is more, olivine has good wear-resisting property and is especially useful in fluidized bed reactor for biomass gasification, which can get rid of the problem of the fragments of the catalyst by friction when catalyst is used as bed material $[16,40,46-49]$. 
TABLE 3: Mass balance for homogeneous catalyst investigation.

\begin{tabular}{lcccccc}
\hline Catalyst & $W_{R} / \mathrm{g}$ & $W_{G} / \mathrm{g}$ & $W_{L} / \mathrm{g}$ & $W_{S} / \mathrm{g}$ & $\left(W_{G}+W_{L}+W_{S}-W_{R}\right) / \mathrm{g}$ & $\begin{array}{c}\text { Mass balance coefficient } \\
Q_{m} / \%\end{array}$ \\
\hline Noncatalytic & 11.3 & 0.49 & 9.94 & 0.54 & 0.33 & 97.09 \\
$\mathrm{LiOH}$ & 12.3 & 0.24 & 10.98 & 0.71 & 0.37 & 96.99 \\
$\mathrm{Na}_{2} \mathrm{CO}_{3}$ & 12.3 & 0.40 & 10.92 & 0.71 & 0.27 & 97.82 \\
$\mathrm{NaOH}$ & 12.3 & 0.34 & 10.15 & 0.87 & 0.94 & 92.36 \\
$\mathrm{~K}_{2} \mathrm{CO}_{3}$ & 12.3 & 0.39 & 10.06 & 0.99 & 0.86 & 93.04 \\
$\mathrm{KOH}$ & 12.3 & 0.36 & 10.48 & 0.77 & 0.69 & 94.39 \\
$\mathrm{Ca}(\mathrm{OH})_{2}$ & 12.3 & 0.31 & 9.32 & 1.39 & 1.29 & 89.52 \\
$\mathrm{ZnCl} 2$ & 12.3 & 0.53 & 9.91 & 0.84 & 1.02 & 91.74 \\
\hline
\end{tabular}

${ }^{\mathrm{a}}$ In the reaction situation with catalyst, all catalyst mass is included in the mass of solid product.

TABLE 4: Experimental results for different homogeneous catalysts.

\begin{tabular}{|c|c|c|c|c|c|c|c|c|c|}
\hline \multirow{2}{*}{ Catalyst } & \multicolumn{4}{|c|}{ Gas yield (mmol/g feedstock) } & \multirow{2}{*}{ CGE (\%) } & \multicolumn{4}{|c|}{ Gas composition (\%) } \\
\hline & $\mathrm{H}_{2}$ & $\mathrm{CO}$ & $\mathrm{CH}_{4}$ & $\mathrm{CO}_{2}$ & & $\mathrm{H}_{2}$ & $\mathrm{CO}$ & $\mathrm{CH}_{4}$ & $\mathrm{CO}_{2}$ \\
\hline Noncatalytic & 2.86 & 2.19 & 1.71 & 6.48 & 23.16 & 21.60 & 16.54 & 12.92 & $\overline{48.94}$ \\
\hline $\mathrm{LiOH}$ & 5.23 & 1.30 & 1.34 & 2.72 & 11.96 & 49.39 & 12.28 & 12.65 & 25.68 \\
\hline $\mathrm{Na}_{2} \mathrm{CO}_{3}$ & 3.14 & 1.43 & 1.42 & 5.42 & 18.46 & 27.52 & 12.53 & 12.45 & 47.50 \\
\hline $\mathrm{NaOH}$ & 3.51 & 0.78 & 1.63 & 4.82 & 16.13 & 32.68 & 7.26 & 15.18 & 44.88 \\
\hline $\mathrm{K}_{2} \mathrm{CO}_{3}$ & 5.64 & 1.08 & 2.55 & 5.09 & 19.44 & 39.28 & 7.52 & 17.76 & 35.45 \\
\hline $\mathrm{KOH}$ & 7.00 & 0.92 & 2.98 & 4.22 & 18.12 & 46.30 & 6.08 & 19.71 & 27.91 \\
\hline $\mathrm{Ca}(\mathrm{OH})_{2}$ & 6.66 & 1.88 & 1.81 & 3.37 & 15.75 & 48.54 & 13.70 & 13.19 & 24.56 \\
\hline $\mathrm{ZnCl}_{2}$ & 5.22 & 1.06 & 2.13 & 7.72 & 24.33 & 32.36 & 6.57 & 13.21 & 47.86 \\
\hline
\end{tabular}

Catalyst, $1 \mathrm{~g}$; feedstock, $1 \mathrm{~g}$ peanut shell + 0.3 g CMC; water density, $0.071 \mathrm{~g} / \mathrm{cm}^{3}$; reaction time, $20 \mathrm{~min}$; pressure, $22 \sim 24.0 \mathrm{MPa}$.

\section{Synergistic Effect of Homogeneous and Heterogeneous Catalyst}

4.1. Influence of the Amount of $\mathrm{NaOH}$. In the process of hydrogen production by biomass gasification in supercritical water when Raney-Ni (RTH-5110 type) is used as catalyst in $400^{\circ} \mathrm{C}$, the liquid obtained is transparent without the smell of tar. When the mixture of Raney-Ni and $\mathrm{NaOH}$ is used as catalyst, the liquid product amount and composition have a great relationship with the amount of $\mathrm{NaOH}$. When the amount of $\mathrm{NaOH}$ is low, the residual liquid is transparent and no char is produced. As the amount of $\mathrm{NaOH}$ increases, the color of residual liquid becomes yellowish-brown and then brown and the smell of tar becomes stronger. It can be seen that the appropriate amount of $\mathrm{NaOH}$ favors biomass gasification and excessive amount of $\mathrm{NaOH}$ has restraining effect.

Mass balance of reactions for peanut shell gasification in supercritical water when $1 \mathrm{~g}$ RTH-5110 type Raney-Ni (in water slurry state) and $0.0 \sim 0.75 \mathrm{~g} \mathrm{NaOH}$ are used as catalyst in $400^{\circ} \mathrm{C}$. The yield of gas increases first and then decreases, and the solid product has increasing trend. The mass balance is within the range of $94.51 \% \sim 99.60 \%$.

In the temperature of $400^{\circ} \mathrm{C}$, initial pressure of $4 \mathrm{MPa}$, the pressure of $24 \sim 28 \mathrm{MPa}$, residence time of $20 \mathrm{~min}$, with the concentration of $10 \mathrm{wt} \%$, and the mixture of $1 \mathrm{~g} \mathrm{RTH}$ 5110 type Raney-Ni (in water slurry state) and $0.0 \sim 0.75 \mathrm{~g}$ $\mathrm{NaOH}$ are used as catalyst. The gasification characteristics of peanut shell in supercritical water can be seen in Figure 1 and the mass balance can be seen in Table 7. It can be seen that as the amount of $\mathrm{NaOH}$ increases, gasification efficiency, carbon gasification efficiency, and hydrogen yield all increase first and then decrease and peak when the amount of $\mathrm{NaOH}$ equals $0.25 \mathrm{~g}$. The gasification efficiency, carbon gasification efficiency, and hydrogen fraction are $110.95 \%, 86.57 \%$, and $172.02 \%$, respectively. Compared with the reaction condition without $\mathrm{NaOH}$, the amplification is $8.48 \%, 15.87 \%$, and $52.37 \%$, respectively. As the amount of $\mathrm{NaOH}$ increases to $0.75 \mathrm{~g}$, the gasification efficiency, carbon gasification efficiency, and hydrogen fraction are $69.11 \%$, $50.64 \%$, and $143.32 \%$. Compared with the reaction condition without $\mathrm{NaOH}$, the decline is $33.36 \%, 20.06 \%$, and $23.67 \%$, respectively.

$\mathrm{NaOH}$ is a catalyst with strong alkaline, and it can enhance hydrogen production by biomass gasification. Meanwhile, when $\mathrm{NaOH}$ and Raney-Ni are mixed, good catalytic effect is obtained. However, the amount of $\mathrm{NaOH}$ has an optimum value and it is speculated that excessive amount of $\mathrm{NaOH}$ has restraining effect on the effect of Raney$\mathrm{Ni}$.

It can be seen from Figure 2 that catalytic effect of different amount of $\mathrm{NaOH}$ is investigated at the reaction temperature of $400^{\circ} \mathrm{C}$, initial pressure of $4 \mathrm{MPa}$, reaction pressure of $24 \sim 28 \mathrm{MPa}$, residence time of $20 \mathrm{~min}$, concentration of feedstock $10 \mathrm{wt} \%$, and $1 \mathrm{~g}$ RTH-5110 Raney-Ni (in water slurry state). It can be observed that as the amount of $\mathrm{NaOH}$ 
TABLE 5: Mass balance for heterogeneous catalyst investigation.

\begin{tabular}{lcccccc}
\hline Catalyst & $W_{R} / \mathrm{g}$ & $W_{G} / \mathrm{g}$ & $W_{L} / \mathrm{g}$ & $W_{S} / \mathrm{g}$ & $\left(W_{G}+W_{L}+W_{S}-W_{R}\right) / \mathrm{g}$ & $\begin{array}{c}\text { Mass balance coefficient } \\
Q_{m} / \%\end{array}$ \\
\hline Noncatalytic & 11.3 & 0.49 & 9.94 & 0.54 & 0.33 & 97.09 \\
R-Ni, RH3110 & 12.3 & 0.24 & 10.98 & 0.71 & 0.37 & 96.99 \\
R-Ni, RH4110 & 12.3 & 0.40 & 10.92 & 0.71 & 0.27 & 97.82 \\
R-Ni, RH5110 & 12.3 & 0.34 & 10.15 & 0.87 & 0.94 & 92.36 \\
Olivine & 12.3 & 0.39 & 10.06 & 0.99 & 0.86 & 93.04 \\
Dolomite & 12.3 & 0.36 & 10.48 & 0.77 & 0.69 & 94.39 \\
\hline
\end{tabular}

TABLE 6: Experimental results for different heterogeneous catalysts.

\begin{tabular}{lccccccrrr}
\hline \multirow{2}{*}{ Catalyst } & \multicolumn{3}{c}{ Gas yield (mmol/g feedstock) } & \multicolumn{2}{c}{ CGE (\%) } & \multicolumn{3}{c}{ Gas composition (\%) } \\
& $\mathrm{H}_{2}$ & $\mathrm{CO}$ & $\mathrm{CH}_{4}$ & $\mathrm{CO}_{2}$ & & $\mathrm{CO}_{2}$ & $\mathrm{CH}_{4}$ & $\mathrm{CO}_{2}$ \\
\hline Noncatalytic & 2.86 & 2.19 & 1.71 & 6.48 & 23.16 & 21.60 & 16.54 & 12.92 & 48.94 \\
R-Ni, RH3110 & 9.57 & 1.63 & 12.11 & 16.18 & 66.73 & 23.92 & 4.07 & 30.26 & 40.43 \\
R-Ni, RH4110 & 8.34 & 1.04 & 10.61 & 15.10 & 59.66 & 23.55 & 2.94 & 29.95 & 42.64 \\
R-Ni, RH5110 & 10.78 & 1.38 & 9.41 & 13.00 & 53.07 & 31.18 & 3.99 & 27.22 & 37.60 \\
Olivine & 4.18 & 0.88 & 1.94 & 7.61 & 23.25 & 28.61 & 6.02 & 13.28 & 52.09 \\
Dolomite & 3.94 & 1.33 & 1.96 & 3.62 & 15.42 & 36.31 & 12.26 & 18.06 & 33.36 \\
\hline
\end{tabular}

Catalyst, $1 \mathrm{~g}$; feedstock, $1 \mathrm{~g}$ peanut shell + 0.3 g CMC; water density, $0.071 \mathrm{~g} / \mathrm{cm}^{3}$; reaction time, $20 \mathrm{~min}$; pressure, 22 24.0 MPa.

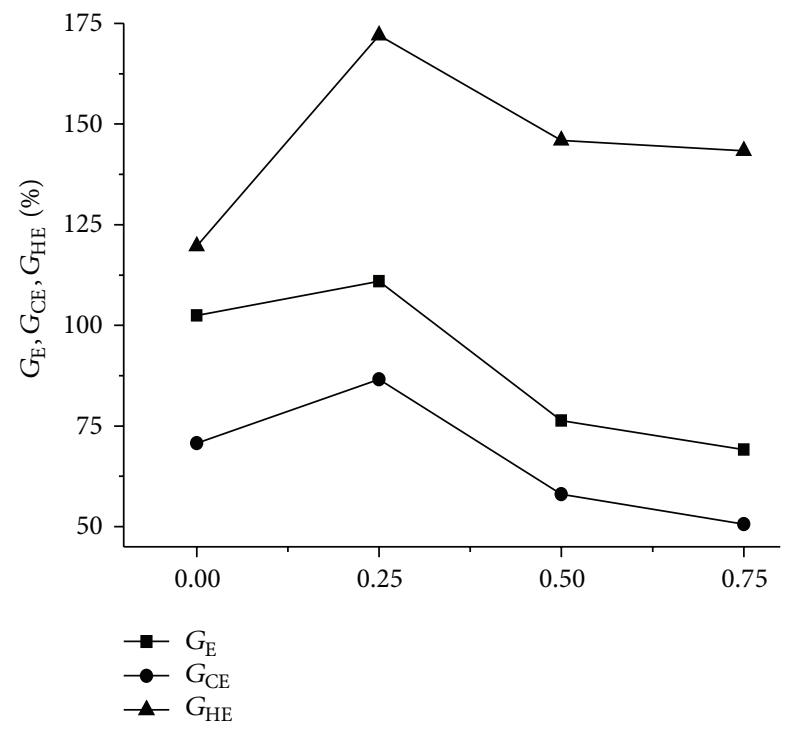

FIGURE 1: The effect of amount of $\mathrm{NaOH}$ upon the hydrogen yield and potential hydrogen yield (water: $\mathrm{CMC}$ : feedstock : Raney-Ni = $10 \mathrm{~g}: 0.3 \mathrm{~g}: 1 \mathrm{~g}: 1 \mathrm{~g}$, temperature: $400^{\circ} \mathrm{C}$, and residence time: $20 \mathrm{~min}$ ).

increases, the hydrogen fraction increases first and then decreases. The fractions of methane and carbon dioxide have decreasing trend, and the fraction of $\mathrm{CO}$ increases slightly and then remains constant. The hydrogen fraction is 59.23\% when the amount of $\mathrm{NaOH}$ is $0.5 \mathrm{~g}$, and the amplification of hydrogen fraction is $28.35 \%$ when the amount of $\mathrm{NaOH}$ is $0.75 \mathrm{~g}$. The fraction of carbon dioxide is $37.23 \%$ with no $\mathrm{NaOH}$ added, while the fraction of carbon dioxide is $23.99 \%$ when the amount of $\mathrm{NaOH}$ is $0.75 \mathrm{~g}$. The fraction of methane

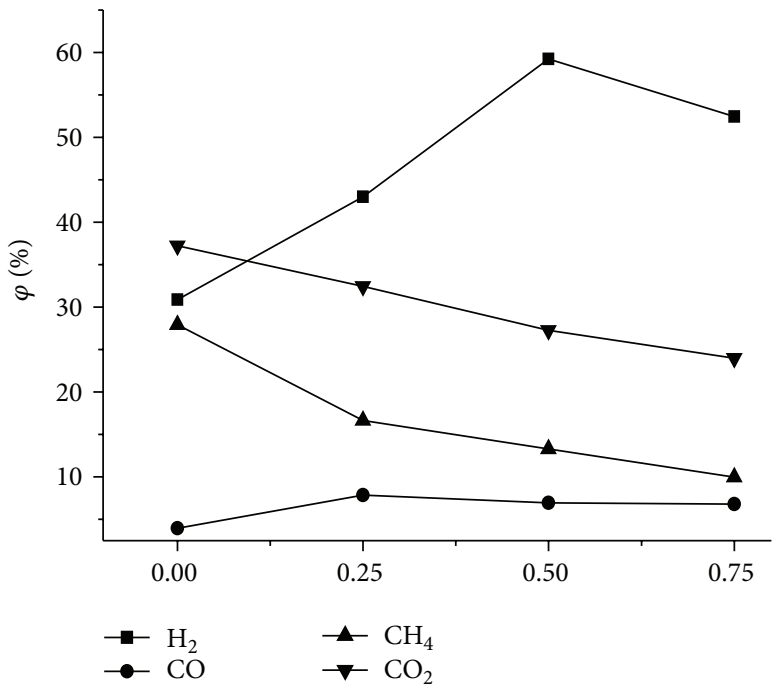

Figure 2: The influence of $\mathrm{NaOH}$ on the gas fraction (\%) (water: CMC : biomass: Raney-Ni $=10 \mathrm{~g}: 0.3 \mathrm{~g}: 01 \mathrm{~g}: 1 \mathrm{~g}$, temperature: $400^{\circ} \mathrm{C}$, and residence time: $20 \mathrm{~min}$ ).

decreases from $27.93 \%$ to $9.97 \%$ when the amount of $\mathrm{NaOH}$ increases from 0 to $0.75 \mathrm{~g}$. It can be seen that the addition of $\mathrm{NaOH}$ can restrain the formation of methane. As a typical basic catalyst, $\mathrm{NaOH}$ can absorb carbon dioxide and promote the water-gas shift reaction toward the direction of hydrogen formation.

Figure 3 shows the hydrogen yield and hydrogen yield potential by supercritical water gasification of peanut shell versus the amount of $\mathrm{NaOH}$. As the amount of $\mathrm{NaOH}$ increases, hydrogen yield and hydrogen yield potential [50] 
TABLE 7: Mass balance for the mixture of $\mathrm{NaOH}$ and Raney-Ni as catalyst.

\begin{tabular}{lcccccc}
\hline Mass of NaOH/g & $W_{R} / \mathrm{g}$ & $W_{G} / \mathrm{g}$ & $W_{L} / \mathrm{g}$ & $W_{S} / \mathrm{g}$ & $\left(W_{G}+W_{L}+W_{S}-W_{R}\right) / \mathrm{g}$ & $\begin{array}{c}\text { Mass balance coefficient } \\
Q_{m} / \%\end{array}$ \\
\hline 0.00 & 12.30 & 1.02 & 10.25 & 0.84 & 0.19 & 98.44 \\
0.25 & 12.55 & 1.11 & 10.46 & 0.93 & 0.05 & 99.60 \\
0.50 & 12.80 & 0.76 & 10.51 & 1.04 & 0.49 & 96.15 \\
0.75 & 13.05 & 0.69 & 10.43 & 1.21 & 0.72 & 94.51 \\
\hline
\end{tabular}

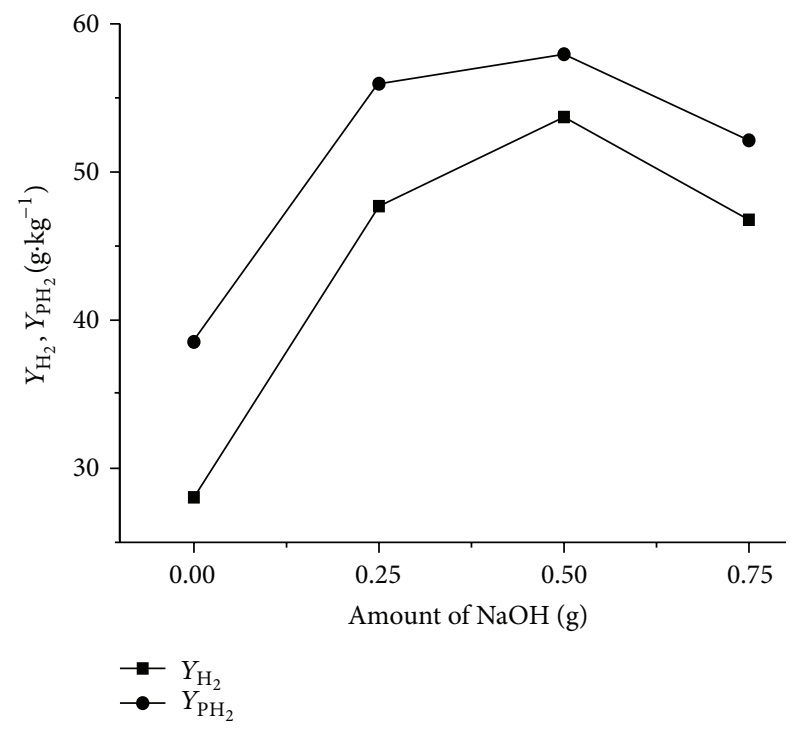

FIGURE 3: The hydrogen yield and hydrogen yield potential by supercritical water gasification of peanut shell versus the amount of $\mathrm{NaOH}$ (water: CMC: biomass: Raney-Ni $=10 \mathrm{~g}: 0.3 \mathrm{~g}: 1 \mathrm{~g}: 1 \mathrm{~g}$, temperature: $400^{\circ} \mathrm{C}$, and residence time: $20 \mathrm{~min}$ ).

by supercritical water gasification of peanut shell increase first and then decrease. When the amount of $\mathrm{NaOH}$ is $0.5 \mathrm{~g}$, they obtained the maximum value. When $\mathrm{NaOH}$ is not present, the hydrogen yield and hydrogen yield potential are $28.02 \mathrm{~g} \cdot \mathrm{kg}^{-1}$ and $38.53 \mathrm{~g} \cdot \mathrm{kg}^{-1}$, respectively. As the amount of $\mathrm{NaOH}$ increases to $0.25 \mathrm{~g}$, the hydrogen yield and hydrogen yield potential are $47.69 \mathrm{~g} \cdot \mathrm{kg}^{-1}$ and $55.95 \mathrm{~g} \cdot \mathrm{kg}^{-1}$, respectively, and the increments are $25.68 \mathrm{~g} \cdot \mathrm{kg}^{-1}$ and $19.41 \mathrm{~g} \cdot \mathrm{kg}^{-1}$, respectively. However, when the amount of $\mathrm{NaOH}$ increases further, the hydrogen yield and hydrogen yield potential decrease. When the amount of $\mathrm{NaOH}$ equals $0.75 \mathrm{~g}$, the hydrogen yield and hydrogen yield potential are $46.77 \mathrm{~g} \cdot \mathrm{kg}^{-1}$ and $52.14 \mathrm{~g} \cdot \mathrm{kg}^{-1}$, respectively. It is presumed that excess amount of $\mathrm{NaOH}$ prevents the contact of the active center and the biomass particle and results in the lower gasification efficiency, carbon gasification efficiency, and hydrogen yield.

4.2. Synergistic Effect of Catalyst. The synergistic effect of Raney-Ni and $\mathrm{NaOH}$ can be seen in Figure 4. The yield of hydrogen by peanut shell supercritical water gasification is $7.44 \mathrm{~g} \cdot \mathrm{kg}^{-1}$ without catalyst. The yield of hydrogen is
$11.43 \mathrm{~g} \cdot \mathrm{kg}^{-1}$ with $\mathrm{NaOH}$ as catalyst and $11.43 \mathrm{~g} \cdot \mathrm{kg}^{-1}$ with RTH5110 Raney-Ni as catalyst. The yield of hydrogen is as high as $53.71 \mathrm{~g} \cdot \mathrm{kg}^{-1}$ when both $\mathrm{NaOH}$ and Raney-Ni are used as catalyst. It can be deduced that the mixing effect of Raney-Ni and $\mathrm{NaOH}$ is as follows:

$$
\begin{aligned}
& (53.71-7.44)-((11.43-7.44)+(28.03-7.44)) \\
& \quad=21.69 \mathrm{~g} \cdot \mathrm{kg}^{-1} .
\end{aligned}
$$

The reason for the synergistic effect of Raney-Ni and $\mathrm{NaOH}$ is analyzed. The process of biomass gasification in supercritical water is a typical multiphase chemical reaction. $\mathrm{NaOH}$ can dissolve in supercritical water to form a uniform slurry, and it can react with biomass particle and leads to the formation of formats, which subsequently degrades to hydrogen and carbon dioxide [18]. Char formation was considerably suppressed. $\mathrm{NaOH}$ could also accelerate the gasification of phenols [20] and reinforce the hydrogenation of phenol to form benzene and further to cyclohexane for hydrogen production [22]. Raney-Ni is a kind of particle catalyst that can react with liquid and gas intermediate. It favors breaking the $\mathrm{C}-\mathrm{C}$ bond and $\mathrm{C}-\mathrm{H}$ bonds to obtain gas and liquid product in small molecular to enhance the carbon conversion at relatively low temperature [40]. Raney-Ni can also future adjust the gas fraction by water-gas shift reaction and methanation reaction. So the Raney- $\mathrm{Ni}$ and $\mathrm{NaOH}$ have a synergistic effect in the biomass gasification in supercritical water.

\section{Conclusion}

Peanut shell is selected as typical biomass to investigate the catalytic gasification result of biomass in supercritical water at the temperature of $400^{\circ} \mathrm{C}$, pressure of $22 \sim 24 \mathrm{MPa}$, and residence time of $20 \mathrm{~min}$. The order of catalytic effect on hydrogen yield of biomass gasification is as follows: $\mathrm{KOH}>$ $\mathrm{Ca}(\mathrm{OH})_{2}>\mathrm{K}_{2} \mathrm{CO}_{3}>\mathrm{LiOH}>\mathrm{NaOH}>\mathrm{Na}_{2} \mathrm{CO}_{3}$. The order of catalytic effect on hydrogen yield of biomass gasification is as follows: $\mathrm{LiOH}>\mathrm{Ca}(\mathrm{OH})_{2}>\mathrm{KOH}>\mathrm{K}_{2} \mathrm{CO}_{3}>$ $\mathrm{NaOH}>\mathrm{Na}_{2} \mathrm{CO}_{3}$. As for Raney-Ni, RTH-3110 has the highest carbon gasification efficiency and RTH-5110 has the highest hydrogen yield. The mixture of Raney-Ni and $\mathrm{NaOH}$ shows great synergistic effect in the process of biomass gasification in supercritical water. 


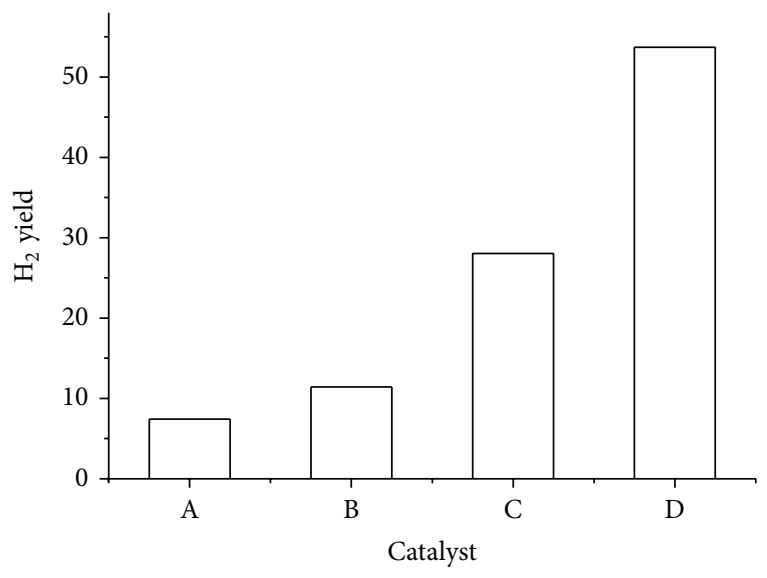

Figure 4: The mixed effect of Raney-Ni and NaOH/g. $\mathrm{kg}^{-1}$. Reaction temperature: $400^{\circ} \mathrm{C}$, reaction pressure: $24 \sim 28 \mathrm{MPa}$, initial pressure: $4 \mathrm{MPa}$, residence time: $20 \mathrm{~min}$, and concentration of feedstock: $10 \%$ (A: none; B: $0.5 \mathrm{~g} \mathrm{NaOH}$; C: $1.0 \mathrm{~g}$ Raney-Ni; D: $0.5 \mathrm{~g} \mathrm{NaOH}+1.0 \mathrm{~g}$ Raney-Ni).

\section{Nomenclature}

$G_{\mathrm{CE}}$ : Carbon gasification efficiency, the mass of carbon element in gaseous product/the mass of carbon in dry matter in the water-coal-slurry

$G_{E}$ : Gasification efficiency, the mass of gaseous product/the mass of dry matter in the water-coal-slurry

$G_{\mathrm{HE}}$ : Hydrogen gasification efficiency, the mass of hydrogen gas/the mass of hydrogen in dry matter in the water-coal-slurry

$W_{G}$ : Sum mass of gas product

$W_{L}$ : Sum mass of liquid product

$W_{R}$ : Sum mass of reactant

$W_{S}$ : Sum mass of solid product

$Y_{\mathrm{H}_{2}}$ : Yield of hydrogen, the mass of certain gas product divided by the mass of dry matter in feedstock

$Y_{\mathrm{PH}_{2}}$ : Hydrogen yield potential, defined as the sum of measured hydrogen and the hydrogen which could theoretically be formed by completely shifting carbon monoxide and completely reforming hydrocarbon species.

\section{Conflict of Interests}

The authors declare that there is no conflict of interests regarding the publication of this paper.

\section{Acknowledgments}

This work was financially supported by the National Natural Science Foundation of China (Contract nos. 51306145 and 51323011) and the National Basic Research Program of China (Contract no. 2012CB215303).

\section{References}

[1] H. Jin, Y. Lu, L. Guo, C. Cao, and X. Zhang, "Hydrogen production by partial oxidative gasification of biomass and its model compounds in supercritical water," International Journal of Hydrogen Energy, vol. 35, no. 7, pp. 3001-3010, 2010.

[2] L. Fiori, M. Valbusa, and D. Castello, "Supercritical water gasification of biomass for $\mathrm{H}_{2}$ production: process design," Bioresource Technology, vol. 121, pp. 139-147, 2012.

[3] E. Kipçak and M. Akgün, "Oxidative gasification of olive mill wastewater as a biomass source in supercritical water: effects on gasification yield and biofuel composition," Journal of Supercritical Fluids, vol. 69, pp. 57-63, 2012.

[4] N. Akiya and P. E. Savage, "Roles of water for chemical reactions in high-temperature water," Chemical Reviews, vol. 102, no. 8, pp. 2725-2750, 2002.

[5] S. Wang, Y. Guo, L. Wang, Y. Wang, D. Xu, and H. Ma, "Supercritical water oxidation of coal: investigation of operating parameters'effects, reaction kinetics and mechanism," Fuel Processing Technology, vol. 92, no. 3, pp. 291-297, 2011.

[6] L. Guo and H. Jin, "Boiling coal in water: hydrogen production and power generation system with zero net $\mathrm{CO}_{2}$ emission based on coal and supercritical water gasification," International Journal of Hydrogen Energy, vol. 38, no. 29, pp. 12953-12967, 2013.

[7] Y. Yoshida, K. Dowaki, Y. Matsumura et al., "Comprehensive comparison of efficiency and $\mathrm{CO}_{2}$ emissions between biomass energy conversion technologies-position of supercritical water gasification in biomass technologies," Biomass \& Bioenergy, vol. 25, no. 3, pp. 257-272, 2003.

[8] M. J. Antal Jr., S. G. Allen, D. Schulman, X. Xu, and R. J. Divilio, "Biomass gasification in supercritical water," Industrial \& Engineering Chemistry Research, vol. 39, no. 11, pp. 40404053, 2000.

[9] Y. E. Gorbaty and A. G. Kalinichev, "Hydrogen bonding in supercritical water. 1. Experimental results," Journal of Physical Chemistry, vol. 99, no. 15, pp. 5336-5340, 1995.

[10] T. Adschiri, Y. Hakuta, and K. Arai, "Hydrothermal synthesis of metal oxide fine particles at supercritical conditions," Industrial \& Engineering Chemistry Research, vol. 39, no. 12, pp. 4901-4907, 2000.

[11] P. E. Savage, "Organic chemical reactions in supercritical water," Chemical Reviews, vol. 99, no. 2-3, pp. 603-621, 1999.

[12] M. D. Bermejo and M. J. Cocero, "Supercritical water oxidation: a technical review," AIChE Journal, vol. 52, no. 11, pp. 3933-3951, 2006.

[13] M. D. Bermejo, M. J. Cocero, and F. Fernández-Polanco, "A process for generating power from the oxidation of coal in supercritical water," Fuel, vol. 83, no. 2, pp. 195-204, 2004.

[14] Y. Lu, L. Guo, X. Zhang, and Q. Yan, “Thermodynamic modeling and analysis of biomass gasification for hydrogen production in supercritical water," Chemical Engineering Journal, vol. 131, no. 1-3, pp. 233-244, 2007.

[15] P. Azadi and R. Farnood, "Review of heterogeneous catalysts for sub- and supercritical water gasification of biomass and wastes," International Journal of Hydrogen Energy, vol. 36, no. 16, pp. 9529-9541, 2011.

[16] H. de Lasa, E. Salaices, J. Mazumder, and R. Lucky, "Catalytic steam gasification of biomass: catalysts, thermodynamics and kinetics," Chemical Reviews, vol. 111, no. 9, pp. 5404-5433, 2011.

[17] Y. Guo, S. Z. Wang, D. H. Xu, Y. M. Gong, H. H. Ma, and X. Y. Tang, "Review of catalytic supercritical water gasification for 
hydrogen production from biomass," Renewable \& Sustainable Energy Reviews, vol. 14, no. 1, pp. 334-343, 2010.

[18] A. Kruse, D. Meier, P. Rimbrecht, and M. Schacht, "Gasification of pyrocatechol in supercritical water in the presence of potassium hydroxide," Industrial \& Engineering Chemistry Research, vol. 39, no. 12, pp. 4842-4848, 2000.

[19] M. B. García Jarana, J. Sánchez-Oneto, J. R. Portela, E. Nebot Sanz, and E. J. Martínez de la Ossa, "Supercritical water gasification of industrial organic wastes," Journal of Supercritical Fluids, vol. 46, no. 3, pp. 329-334, 2008.

[20] Z. R. Xu, W. Zhu, M. Gong, and H. W. Zhang, "Direct gasification of dewatered sewage sludge in supercritical waterpart 1: effects of alkali salts," International Journal of Hydrogen Energy, vol. 38, no. 10, pp. 3963-3972, 2013.

[21] C. Cao, L. Guo, H. Jin, S. Guo, Y. Lu, and X. Zhang, “The influence of alkali precipitation on supercritical water gasification of glucose and the alkali recovery in fluidized-bed reactor," International Journal of Hydrogen Energy, vol. 38, no. 30, pp. 13293-13299, 2013.

[22] Y. Guo, S. Z. Wang, Y. Z. Wang, J. Zhang, D. H. Xu, and Y. M. Gong, "Gasification of two and three-components mixture in supercritical water: influence of $\mathrm{NaOH}$ and initial reactants of acetic acid and phenol," International Journal of Hydrogen Energy, vol. 37, no. 3, pp. 2278-2286, 2012.

[23] Y. Li, L. Guo, X. Zhang, H. Jin, and Y. Lu, "Hydrogen production from coal gasification in supercritical water with a continuous flowing system," International Journal of Hydrogen Energy, vol. 35, no. 7, pp. 3036-3045, 2010.

[24] S. Guo, L. Guo, C. Cao, J. Yin, Y. Lu, and X. Zhang, "Hydrogen production from glycerol by supercritical water gasification in a continuous flow tubular reactor," International Journal of Hydrogen Energy, vol. 37, no. 7, pp. 5559-5568, 2012.

[25] H. Schmieder, J. Abeln, N. Boukis et al., "Hydrothermal gasification of biomass and organic wastes," Journal of Supercritical Fluids, vol. 17, no. 2, pp. 145-153, 2000.

[26] A. Sinağ, A. Kruse, and V. Schwarzkopf, "Key compounds of the hydropyrolysis of glucose in supercritical water in the presence of $\mathrm{K}_{2} \mathrm{CO}_{3}$," Industrial \& Engineering Chemistry Research, vol. 42, no. 15 , pp. 3516-3521, 2003.

[27] K. S. Lin, H. P. Wang, and M. C. Li, "Oxidation of 2,4dichlorophenol in supercritical water," Chemosphere, vol. 36, no. 9, pp. 2075-2083, 1998.

[28] S. Y. Lin, M. Harada, Y. Suzuki, and H. Hatano, "Continuous experiment regarding hydrogen production by $\mathrm{Coal} / \mathrm{CaO}$ reaction with steam (II) solid formation," Fuel, vol. 85, no. 7-8, pp. 1143-1150, 2006.

[29] H. Ramsurn, S. Kumar, and R. B. Gupta, "Enhancement of biochar gasification in alkali hydrothermal medium by passivation of inorganic components using $\mathrm{Ca}(\mathrm{OH})_{2}$, Energy \& Fuels, vol. 25, no. 5, pp. 2389-2398, 2011.

[30] P. D'Jesús, N. Boukis, B. Kraushaar-Czarnetzki, and E. Dinjus, "Gasification of corn and clover grass in supercritical water," Fuel, vol. 85, no. 7-8, pp. 1032-1038, 2006.

[31] C. F. Wu and P. T. Williams, "Hydrogen production by steam gasification of polypropylene with various nickel catalysts," Applied Catalysis B: Environmental, vol. 87, no. 3-4, pp. 152-161, 2009.

[32] L. H. Zhang, C. B. Xu, and P. Champagne, "Activity and stability of a novel Ru modified Ni catalyst for hydrogen generation by supercritical water gasification of glucose," Fuel, vol. 96, pp. 541$545,2012$.
[33] P. Azadi, E. Afif, H. Foroughi, T. S. Dai, F. Azadi, and R. Farnood, "Catalytic reforming of activated sludge model compounds in supercritical water using nickel and ruthenium catalysts," Applied Catalysis B: Environmental, vol. 134-135, pp. 265-273, 2013.

[34] P. Azadi, S. Khan, F. Strobel, F. Azadi, and R. Farnood, "Hydrogen production from cellulose, lignin, bark and model carbohydrates in supercritical water using nickel and ruthenium catalysts," Applied Catalysis B: Environmental, vol. 117-118, pp. 330-338, 2012.

[35] Y. Matsumura, X. Xu, and M. J. Antal, "Gasification characteristics of an activated carbon in supercritical water," Carbon, vol. 35, no. 6, pp. 819-824, 1997.

[36] X. D. Xu, Y. Matsumura, J. Stenberg, and M. J. Antal, “Carboncatalyzed gasification of organic feedstocks in supercritical water," Industrial \& Engineering Chemistry Research, vol. 35, no. 8, pp. 2522-2530, 1996.

[37] D. C. Elliott, "Catalytic hydrothermal gasification of biomass," Biofuels, Bioproducts \& Biorefining, vol. 2, no. 3, pp. 254-265, 2008.

[38] M. Osada, O. Sato, K. Arai, and M. Shirai, "Stability of supported ruthenium catalysts for lignin gasification in supercritical water," Energy \& Fuels, vol. 20, no. 6, pp. 2337-2343, 2006.

[39] A. J. Byrd, K. K. Pant, and R. B. Gupta, "Hydrogen production from glucose using $\mathrm{Ru} / \mathrm{Al}_{2} \mathrm{O}_{3}$ catalyst in supercritical water," Industrial \& Engineering Chemistry Research, vol. 46, no. 11, pp. 3574-3579, 2007.

[40] T. Minowa and T. Ogi, "Hydrogen production from cellulose using a reduced nickel catalyst," Catalysis Today, vol. 45, no. 14, pp. 411-416, 1998.

[41] X. Hao, L. Guo, X. Zhang, and Y. Guan, "Hydrogen production from catalytic gasification of cellulose in supercritical water," Chemical Engineering Journal, vol. 110, no. 1-3, pp. 57-65, 2005.

[42] A. Sinaǧ, A. Kruse, and J. Rathert, "Influence of the heating rate and the type of catalyst on the formation of key intermediates and on the generation of gases during hydropyrolysis of glucose in supercritical water in a batch reactor," Industrial \& Engineering Chemistry Research, vol. 43, no. 2, pp. 502-508, 2004.

[43] J. M. Encinar, F. J. Beltrán, A. Ramiro, and J. F. González, "Pyrolysis/gasification of agricultural residues by carbon dioxide in the presence of different additives: influence of variables," Fuel Processing Technology, vol. 55, no. 3, pp. 219-233, 1998.

[44] A. Pei, L. Guo, and H. Jin, "Experimental research on catalysts and their catalytic mechanism for hydrogen production by gasification of peanut shell in supercritical water," Frontiers of Energy and Power Engineering in China, vol. 1, no. 4, pp. 451456, 2007.

[45] A. Pei, L. Zhang, B. Jiang et al., "Hydrogen production by biomass gasification in supercritical or subcritical water with Raney-Ni and other catalysts," Frontiers of Energy and Power Engineering in China, vol. 3, no. 4, pp. 456-464, 2009.

[46] S. Morrin, P. Lettieri, C. Chapman, and L. Mazzei, "Two stage fluid bed-plasma gasification process for solid waste valorisation: technical review and preliminary thermodynamic modelling of sulphur emissions," Waste Management, vol. 32, no. 4, pp. 676-684, 2012.

[47] Y. Li and Z. Wu, "Effects of catalytic cracking conditions on biomass tar cracking," Journal of Tsinghua University, vol. 49, no. 2, pp. 253-256, 2009.

[48] P. A. Simell, J. K. Leppälahti, and J. B.-S. Bredenberg, "Catalytic purification of tarry fuel gas with carbonate rocks and ferrous materials," Fuel, vol. 71, no. 2, pp. 211-218, 1992. 
[49] V. Vassilatos, G. Taralas, K. Sjostrom, and E. Bjornbom, "Catalytic cracking of tar in biomass pyrolysis gas in the presence of calcined dolomite," Canadian Journal of Chemical Engineering, vol. 70, no. 5, pp. 1008-1013, 1992.

[50] S. Turn, C. Kinoshita, Z. Zhang, D. Ishimura, and J. Zhou, "An experimental investigation of hydrogen production from biomass gasification," International Journal of Hydrogen Energy, vol. 23, no. 8, pp. 641-648, 1998. 

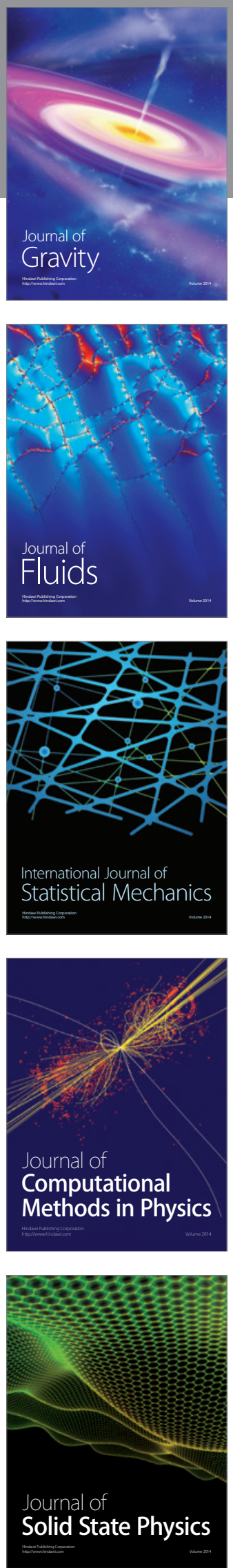

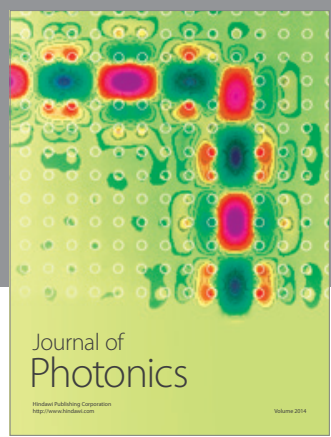

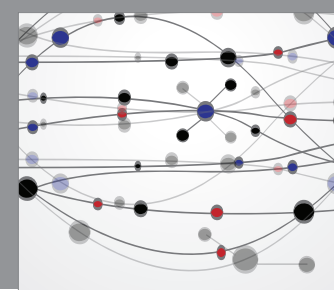

The Scientific World Journal

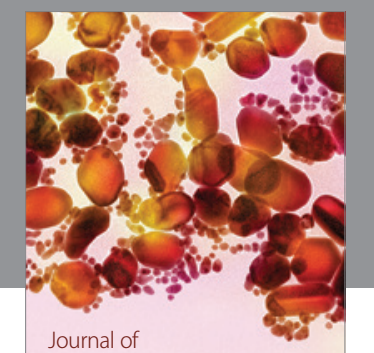

Soft Matter
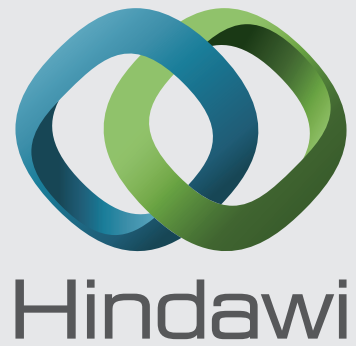

Submit your manuscripts at

http://www.hindawi.com
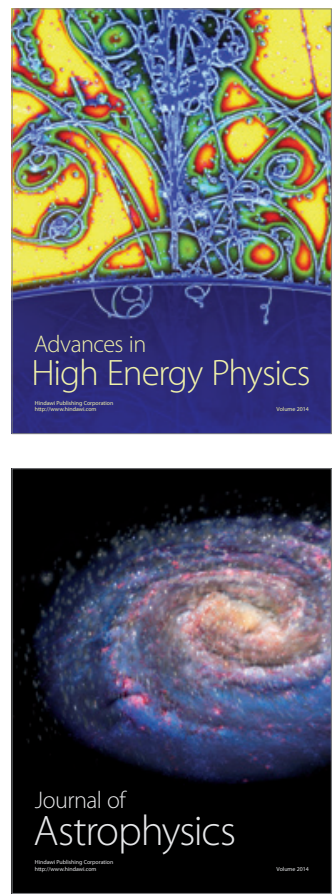
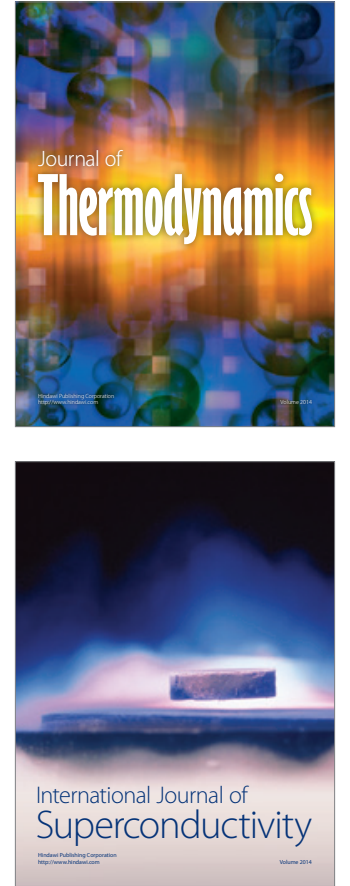
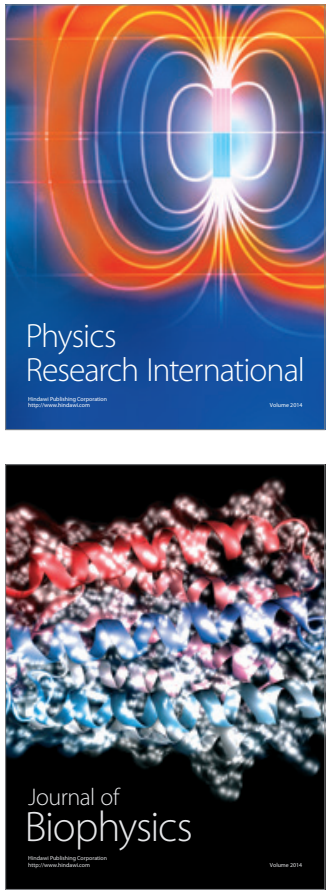
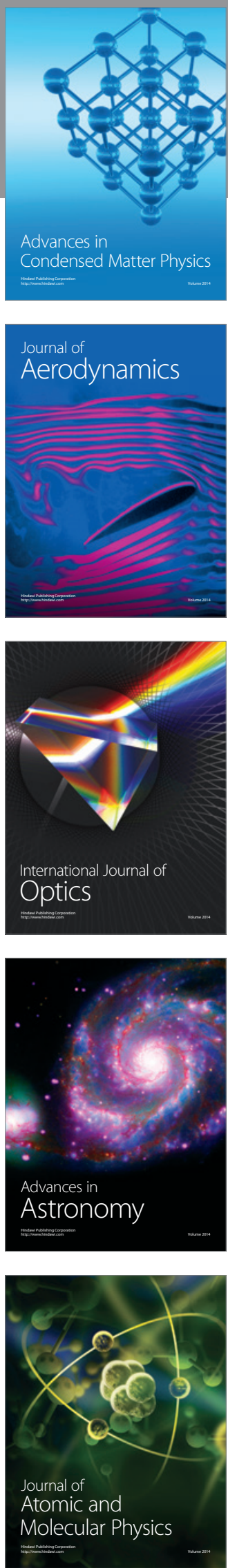